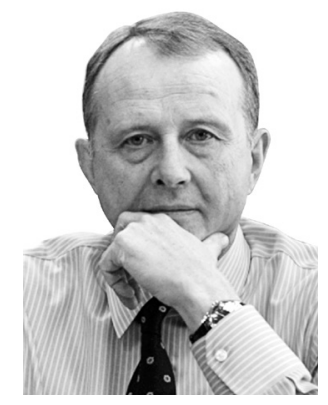

Aleksandr A. DYNKIN

Academician of the Russian Academy of Sciences,

Dr. Sc. (Econ.), Prof., President

Primakov National Research Institute of World Economy

and International Relations

23 Profsoyuznaya St., Moscow, Russia, 117997

Phone: (499) 128-05-14

e-mail: dynkin@imemo.ru

\title{
Russia's Economy: Domestic Discussions and International Positioning
}

\begin{abstract}
The paper explores the issue of priorities and a vector of the Russian economy development in the context of the country's positioning in the international arena. The author identifies economic cycles in Russia's recent history and reveals the specific features of the crisis of 2014 and peculiarities of the economic recovery afterwards. The author argues that within the country there are growth areas, which can become sources of the economy's sustainable development. At the same time, there are three key factors that may hinder achievement of economic goals by Russia: a slowdown in China's economic growth; potential increase in oil production; deterioration of the business climate and negative expectations of economic actors in the leading countries of the European Union. These and other factors, along with unresolved problems of innovative activities and technologies' competition in Russia, can adversely affect the expected growth of the domestic economy of $1.5-2 \%$ of GDP.
\end{abstract}

\section{JEL classification: F01, P24}

Keywords: sustainable growth; industrial policy; innovations; technological competition; structural reforms; institutional modernisation.

\section{Instead of an introduction: 0 n the content of economic debates}

$\mathrm{P}$ olemics over the concept of economic policy is an inherent part of public discourse (see, for instance [6;11]). It did not subside even during the period of high economic growth. At that time, it was mainly fueled by the interests linked with redistribution of limited resources in favour of one or another industry, or the interests of a group of banks under the slogan of "industrial policy".

When searching for a new model of development its aggravation occurs naturally. It is normal, but the fact chagrins that the model is shopworn. In essence, for the last 25 years it has been limited to the polemics over two basic ideas:

- strengthening market instruments of state regulation, passing structural reforms, using competition as a driver of growth, conducting a responsible monetary policy; or

- credit expansion as a source of investment directed to centrally identified priorities, because inflation is the lesser evil and state planning is the optimal way to accelerate economic growth [14].

It seems that the discussion, with minor variations, still remains within the naive dichotomy of the second half of the 1980 s: "plan or market" $[4 ; 5 ; 8 ; 12]$. The ideological basis of opponents rests on the rejection of the foundations of competitive market economy. One can easily recall the fiery fight with accession to the WTO. Professional analysis showed that this event, without structural reforms, is neutral with respect to economic growth rates. Reality has

${ }^{1}$ In the $1990 s$ the slogan was "conversion" (the transfer of enterprises of the defence industry to the production of consumer goods). 
completely confirmed it. Today, in addition to the far-left ideology, there are very specific lobbying aspirations and the desire to offer oneself to high positions in the economic bloc of the executive or legislative power. It is sad that ideology, lobbyism and career interests still often dominate national goals. It is completely unacceptable that such views are very far from the current level of economic knowledge.

\section{Cycles in economy: Essence and reasons}

A well-known fact, which no longer requires proof, because it has been quite exhaustively researched (see for example, $[7 ; 9 ; 16]$ ), is that the economy develops cyclically.

The completed economic recession is the third in the history of the new Russia. The first two recessions in 1998 and 2008 were clearly V-shaped. If in 1998 GDP fell by 5.3\%, then in 1999 there was an increase of $6.4 \%$, and in 2000 it reached $10 \%{ }^{1}$. This is a record growth over the past 30-35 years. A similar picture was in 2009.

The decline that ended in 2016 was not so deep, but was lengthier. Graphically, it can be represented by a U-shaped or, at worst, L-shaped curve. In accordance with the inertial forecast of the Ministry of Finance of the Russian Federation, the economic growth rates in Russia may be below the world average during the next 10 years. The $\mathrm{IMF}^{2}$ projected a recovery in 2017 ( $+1 \%$ of GDP), and in 2020 and 2021 it expects $+1.5 \%$ of GDP. The reality is somewhat better: the Ministry of Economy of the Russian Federation forecasts growth of $2 \%$ in $2017^{3}$.

How does it affect the country's positioning in the world? In 2015, Russia was the sixth economy in the world by purchasing power parity and the $13^{\text {th }}$ by the current exchange rate. If Russia keeps this sluggish economic dynamics, by 2030 it can drop to the seventh place in the world by parity, being outrun by Brazil. Judging by the current exchange rate, the fall may be even to the $15^{\text {th }}$ place, just after Mexico. Today the two countries, Brazil and Mexico, are Russia's actual competitors.

What are the reasons behind this situation? First, in 2014-2015 the so-called resource cycle ended, and the world economy entered a period of low commodity prices. As a result, the Russian economy, heavily tied to global commodity markets, is now suffering from the consequences of the Dutch disease and addiction to high oil prices during fifteen years. Second, the export-oriented growth model, based on a constant increase in export prices of hydrocarbons, is exhausted.

However, the period of 1999-2008, when the annual average growth rate amounted to $7.7 \%$ and which some observers called the "Russian economic miracle", gave a long-awaited respite, after the hardest and dramatic transformation shock of 1992-1998.

During this period, the foundations of market institutions, even if not perfect ones, were laid. The first step in this direction was taken by the Government of Ye. M. Primakov that for the first time in the history of the new Russia balanced the budget for 1999. The political stability brought by V.V. Putin elected President and responsible, professional macroeconomic policy adopted by A. L. Kudrin and G. O. Gref supported the rapid growth of 2000-2008.

Certainly, the favourable situation in the world commodity markets "was raising the sails" of the Russian economy in those years. The real effective rate of the ruble in 2013 exceeded the estimated inflation rate by approximately $35 \%$. In other words, the incomes of households and enterprises consisted by more than a third of oil rent. At the same time, labour productivity grew much more slowly. Nevertheless, a number of sectors of the economy (metallurgy, food industry, chemistry, mobile communications, banks, health care, etc.) were able to modernize their fixed capital significantly. Households built up a little nest egg. Over the past 15 years, the

\footnotetext{
${ }^{1}$ Data of the Federal State Statistics Service of Russia. Available at: http://www.gks.ru.

${ }^{2}$ Data for July 2016. Available at: http://www.imf.org/external/russian.

${ }^{3}$ Available at: http://economy.gov.ru/minec/about/structure/depMacro/2017130403.
} 
average floor area per person in Russia has grown by almost a quarter. In households, a certain stock of the newest durable goods has been formed. Over 300 billion US dollars today is on bank deposits and, probably, the same amount is stored in cash.

In 2014-2015, there was no banking panic, as it was in 1998-1999 or even the start of it, as it was in the autumn of 2008. It was eliminated at a fairly expensive price. Households and companies gained a specific experience of crisis strategies.

In particular, households changed the consumer behavior model to the saving one. In January 2016, deposits of individuals in financial and credit institutions increased by $27 \%{ }^{1}$ compared to January 2015. The indebtedness of Russians has also decreased. And, if in 1998 many thought that the sky was falling to the ground, today there is no such kind of feeling.

The positive foreign trade balance has remained approximately the same. The gold and foreign exchange reserves are also relatively high. Yet the drop in household incomes has been very sharp and has brought the country back to the level of ten years ago.

Under the current conditions, the Russian economy is taking a growth trajectory, especially if the demand is going to be supported through pensioners and public sector employees. However, the rate is close to the weak growth of the leading countries of the European Union, that is, about $1.5-2 \%$ a year. Yet the Russian economy, with the huge deferred consumer demand for health care, education, housing, the economy's demand for infrastructure, modernisation of many industries that are still far from the technological frontier, has much greater growth potential than highly developed European economies.

At the same time, the risks of protracted stagnation are huge. In 2010-2015 the average annual rate of economic growth was $1.7 \%$ of GDP. Thus, transition to a new model of economic development is extremely needed.

\section{Prerequisites and obstacles to sustainable growth}

What opportunities are there for overcoming the economic downturn? First, the ones linked with switching part of the demand to domestically produced goods. The economy has gradually adapted to new price proportions. Idle capacity has appeared, though with retained workforce, including in the form of part-time employment. Without the possibility of an easy external refinancing, companies' balance sheets are improving noticeably. Some industries have demonstrated marked growth even in the midst of the recession (in 2015). For instance, the chemical industry production increased by $6.2 \%$, agriculture demonstrated growth of $3.0 \%{ }^{2}$. All this leaves room for a recovery.

Still, a critical obstacle on this path is a drop in investment. Elementary investment analysis is based on the ratio of profitability to risk. Risks in the Russian economy, in our opinion, are stratospheric. There are often calls to lower lending rates in Russia with the reference to low interest rates in Japan, the USA and the EU. However, as long as in the country there are timeconsuming procedures of acquiring land and getting energy network connections, multi-stage clearance of export operations, intricate VAT refund procedures for exports, raiding, discriminatory access to the logistics infrastructure, other chronic regulatory impediments, lending rates, which are set on the basis of market principles, will not ignore these and other risks.

Moreover, there is a constant increase in the regulatory and tax costs of business. For the past 15 years the volume of the Code of Administrative Offences has grown 2.7 times. If in the first half of 2000, 1,717 federal regulations were issued, then in the first half of 20155,169 federal regulations were brought in, i.e. 28 federal acts a day, counting the weekend. How can, for instance, a vice-governor for economics and finance in an average region survive this regulatory "shower", which falls on them every day? The same is true for medium-sized companies. Large companies, obviously, have dozens of lawyers and can manage this flow.

\footnotetext{
${ }^{1}$ Data of the Federal State Statistics Service of Russia. Available at: http://www.gks.ru.

${ }^{2}$ Ibid.
} 
What does this lead to? In the winter of 2016, the processing of one container in the port of Vladivostok, including customs clearance, took 72 hours. Approximately $750 \mathrm{~km}$ to the south of the port of Vladivostok there is the Chinese port of Dalian (formerly - Dalniy port), and it takes 18 minutes to process a container there. And until Russia does not approach the leaders of the modern world economy in this and other parameters of public administration, it is extremely irresponsible to suggest that the national economy should attract as much investments as possible.

The above-mentioned examples are a brief sketch of the failures of public administration. Its reform together with judicial reform is the best crisis and countercyclical policy that will help entering the path of sustainable growth [17].

Another serious limitation to growth is the quality of human capital. According to the human development index, Russia and Belarus rank the $50^{\text {th }}$-the $51^{\text {st }}$ in the world, and there are no major changes in the rating, since the life expectancy remains at the same level for many years. According to the World Health Organisation, Russia occupies the $122^{\text {nd }}$ place in the world by this indicator. The average life expectancy in Russia is 70.9 years. In North Korea it equals 70.5 years, in China it is already 75, and in neighboring Finland it is 81 years.

Obviously, Central Russia is emptying. In Pskov, Tula, Tver, Novgorod, Ryazan, Vladimir and other central oblasts, the mortality rate is the highest, while the birth rate is $1.5-2$ times lower than the national average. The bad news is that the megacities, namely Moscow and Saint Petersburg, are dragging young people from the central regions. According to some estimates, $60 \%$ of the working-age population of Ivanovo work in Moscow.

This spatial unevenness of economic development is a serious challenge, which has not been adequately addressed yet. The most appropriate response to it, in our opinion, is the development of infrastructure, first and foremost, roads, gas distribution network, and, definitely, the development of agricultural and small business.

If a clear economic strategy is designed for the medium term to reduce uncertainty in the economy and provide more freedom to business by curbing the regulatory burden, increasing the speed and quality of public services, as well as if the ruble exchange rate is going to be relatively low, we can count on resumption of economic growth. It may be higher than in China, but a 3-4\% increase of in GDP per year is a realistic estimate. It is based on the economy's need for technological modernisation and infrastructure development, as well as considerable deferred consumer demand.

Generally, since the days of the Politburo of the Central Committee of the Communist Party of the Soviet Union, there has been some kind of obsession with the growth rates. Academician S. G. Strumilin suggested to N.S. Khrushchev that a "sanitary" five-year plan to eliminate structural imbalances should be arranged. In 1980, academician A.I. Anchishkin used calculations of intersectoral balances and reached, from his viewpoint, the optimal figure of $0.8 \%$ of GDP growth per year [1]. He stressed the importance of qualitative characteristics of the structure of output. Yet he was not listened to as well and was forced to change his calculations to $4 \%$. From our standpoint, it is necessary to return to the priority of quality of growth over the rates.

Proponents of high growth rates at any price offer various combinations of credit expansion, for instance, investment money, the use of artificial schemes of financial engineering in the hope of financing priority knowledge-intensive industries, small and medium-sized businesses or simply innovations. They often refer to the experience of the Federal Reserve System of the United States or the European Central Bank, which practiced quantitative easing that did not result in inflation. All this would have been possible, only if Russia could have issued dollars or euros, but not rubles. These currencies have virtually unlimited global demand, are an attractive financial asset. Unfortunately, this cannot be said about Russia's currency. The vigorous campaign for turning Moscow into an international financial center passed over without any consequences. Instead, artificial financial schemes are proposed to 
keep investment money from hitting the currency or consumer markets. These proposals partly resemble the utopian "three models of khozraschyot" be implemented under three simultaneously satisfied conditions: abolishing convertibility of the ruble, introducing creation of specific funds and rationing system, and applying multiple exchange rates. However, such practices are not possible without the restoration of Gosplan, Gossnab, Goskomtsen of the USSR ${ }^{2}$ and other attributes of the failed planned economy (a good example is the economic program of "acceleration on the basis of machine-building", which brought down the Soviet economy). In fact, proponents of pumping up economy with money are calling for actually bankrupt economic strategies. Existing experience also suggests that for one more or less effective (it is still early to judge) Superjet there are tens of yo-mobils ${ }^{3}$ and other poor quality products.

Undoubtedly, a balanced monetary policy is a necessary, but not sufficient, condition for growth. Journalists often ask a question: How can the economy benefit from it? The answer is "in no way", though a bad monetary policy, which fosters money creation, is capable of undermining social and political stability. Therefore, it is counterproductive to reject a moderately tight monetary policy. The political difficulty in pursuing a tight monetary policy or the policy of reorganizing the banking system is that it incurs a concentrated damage to expectations or even direct financial losses to insiders along with an ill-defined social gain, which is not always immediately noticeable. The ideas of the key rate being higher than the current inflation or increasing the national debt can be discussed, but quantitative easing, while the ruble is not a global asset, is not a solution to the problems of the Russian economy.

\section{Structural reforms and institutional modernisation}

In order to lay the foundation for sustainable economic growth, structural and institutional reforms are needed $[13 ; 18]$. The Edict of May 16, 2016 issued by V.V. Putin established the Working Group of the Economic Council under the President of the Russian Federation led by A.L. Kudrin. The name of the group unambiguously speaks about its mission: "Priorities of structural reforms and sustainable economic growth". Since shock reforms are always extremely painful, it is essential to enter gradually into new economic realities. For the period of overcoming the recession, in our view, it is necessary to declare a moratorium on new legislative initiatives and regulations that worsen the conditions of economic activities.

The terms of government procurement through tenders should be radically simplified. At the moment, the tender system is focused on the procedure, and not on the final result. It is necessary to remove export barriers for medium-sized companies and move steadily towards such well-known by economists of different schools institutions as the competitive environment of domestic markets, investor protection and the effective judiciary. All these are structural reforms that have been long talked about (see, for example, $[2 ; 3 ; 6]$ ).

Only structural reforms aimed at fostering competitive climate will allow overcoming innovative apathy [10]. In the sphere of innovations, a paradoxical situation has developed. As a result of the massive and not always critical borrowing of foreign institutions, practices and procedures in Russia, almost all structural elements of the standard Anglo-Saxon innovation system have been formed. There are research universities and state scientific and venture funds, an innovation center, industrial parks, even a section of new high-tech companies on the Moscow Interbank Currency Exchange (MICEX). The only thing that is absent is innovations.

${ }^{1}$ Khozraschyot is a method of the planned running of an economic unit (i.e., of a business) based on the confrontation of the expenses incurred in production with the production output, on the compensation of expenses with the income within one economic unit.

${ }^{2}$ State Planning Committee, State Supplies, State Committee on Prices of the USSR.

3 The yo-mobil was a planned series of hybrid electric cars that was going to be manufactured by the Russian Yo-auto. As of 2017, no vehicles were ever produced. 
In our opinion, the idea that innovation is an exclusively market, economic event has not taken root yet. This is not a technological breakthrough, not a new discovery or invention. Innovation (a product or a service), is born at the point of intersection of social need (in other words - effective demand) and technology. Innovation should not be "introduced" - it is quite another story. Even if it is from the sixth or any other technological mode. The actual change of the situation here is again connected with structural reforms. The fact is that until the victory in market competition is brought solely by involvement of administrative resources, rather than competition for market share and consumers on the basis of high-quality innovation effects, business will not focus its strategies on creating and using innovations. V. V. Putin's visit in mid-2016 to the plant of the Acron Group in Veliky Novgorod ${ }^{1}$ showed that in Russia there are globally competitive enterprises that invest heavily in technology, relying on domestic scientific and engineering organisations. And this, in particular, is the result of the competent policy of regulators (Federal Antimonopoly Service, Ministry of Industry), which formed a competitive climate in the mineral fertilizer industry.

Structural reforms in the state regulation, public administration, judiciary will allow retaining competitive positions in such sectors as oil production, chemical industry, agriculture, nuclear, transport, and agricultural machine-building, helicopter construction, communications, banking, construction materials production, robotics. In these sectors, there is both domestic and overseas demand. In addition, today a serious state support is provided to the automotive industry, agriculture and construction. These sectors can become a starting point for moving deeper into the technological space, into technologically related industries on the basis of the so-called organic structural growth. Borrowing technologies, becoming a part of global value chains is an inevitable process on this path, but we must strive to ensure that profit centers and centers of system integration of technologies move to the territory of Russia. Yet we should not forget that services account for $65 \%$ of the national GDP, which means here there is room for growth as well. For instance, at the moment domestic tourism demonstrates an obvious growth of investments.

Sectors involved in maintaining homeland security naturally need government procurement, though even here there are opportunities for optimisation, including through the production of non-military or dual use items, due to the emphasis on the so-called dual innovations.

\section{Challenges of the global economy as the risks to sustainable development of the Russian economy}

There are three factors determining risks to sustainable development of the Russian economy:

1. The slowdown in the Chinese economy, which can influence the development of Russia in the coming years. Official statistics indicate that in 2015 the rate of economic growth in China amounted to $6.9 \%$, which was the lowest in this country for the last quarter century. Most Western and Japanese experts believe that China's real growth is even lower, probably less than $5 \%$. Generally, it is normal, because 1\% of China's GDP today is $1.5 \%$ in 2010 and $2.5 \%$ in 2000 . For Russia, the negative impact is sensitive for the most part due to pressure on hydrocarbon prices.

2. Additional pressure on energy markets resulting from the return of Iran to the export of hydrocarbons, the increase in the production of shale oil and gas in the USA. The increase in the supply of hydrocarbons from the USA and Iran may change the balance in the oil market, although the exports of these countries are expected to be significant in mid-2018.

3. Deterioration of the business climate and the negative expectations of economic actors in the leading EU countries related to the refugee problem, the UK's withdrawal from the $\mathrm{EU}$ and, of course, the terrorist threat. Sluggish economic dynamics in Europe can affect the

${ }^{1}$ Available at: http://www.velikiynovgorod.ru/news/actions/v_prisutstvii_vladimira_putina_zapushchen_novyy_proekt_akrona_ammiak_4. (in Russ.) 
supply of investment products from the EU countries and volumes of the Russian exports, because despite the sanctions, the EU remains Russia's leading trading partner. The EU accounted for $48 \%$ of the Russian exports and $38 \%$ of imports last year.

As for cooperation with China, it requires realism without excessive illusions. There was a period when some officials and experts were greatly afraid of Chinese expansion to the Far East. That did not happen. Today, Far Easterners are more likely to go to China. Similarly, prophecy that "China will help us" does not come true as well. In 2015, the volume of the Chinese direct investment in the USA was approximately 26 times higher than the volume of these investments in Russia. Of China's 39 billion foreign direct investment abroad last year, we received only $1.5 \%$. This once again confirms that both Shanghai and London bankers use the same financial models, equally taking into account country risks.

China will not be able to replace cooperation with Europe and the United States in the technological, energy and investment spheres. At the same time, the Chinese vector is a very important and growing strategic addition to the European vector, especially taking into account the plans of the leadership of the PRC to turn the country into a world technological front-runner. According to forecasts of Primakov National Research Institute of World Economy and International Relations, by 2030 China's share in the structure of global spending on $\mathrm{R} \& \mathrm{D}$ will exceed the share of all EU countries.

China retains the position of Russia's main trading partner, and the new opportunities for Russia in terms of attracting Chinese investment are opened up by the strategy of the Silk Road Economic Belt and the Asian Infrastructure Investment Bank as its financial base. However, this opportunity needs decisive actions. Particularly, steps should be taken to implement the agreement on the interface of the Silk Road and plans for the development of the Eurasian Economic Union.

Relations with the East require an active policy, because the Russian direction is far from being the only one and the main thing in the plans of the Silk Road, which today gives priority to Kazakhstan, Pakistan and Eastern Europe via the southern routes, without Russia and Ukraine's involvement. China has already began investing in the Pakistani-Kazakhstan and Eastern Europe corridors (the volume of investments is 40 billion US dollars), bypassing Ukraine and Russia. Cooperation between China and 16 former socialist countries is actively developing. And there is a high probability that these southern corridors will be created earlier than the meridian transport corridors "south-north", which are of more interest to us.

\section{Technological competition}

In its $13^{\text {th }}$ Five-Year Plan China unequivocally stated that the country is striving to become the world's innovative front-runner. By 2020 the leadership of the PRC is going to increase spending on $\mathrm{R} \& \mathrm{D}$ by $2.5 \%$ of GDP, which is very high. The reason behind this is that the number of players in the global high-tech markets is growing, and the competition for the so-called innovation premium is becoming more acute. In addition, many technological solutions reached their limits, primarily from the ecological and demographical viewpoints. Finally, hopes of corporations to seize and retain global leadership are tightly linked with the innovative superiority of the state. A turn from a front-line approach to science and innovation to focusing resources is taking place. The resources become focused on the subject and structure, which are obvious national and international leaders [15; 19].

An appropriate organisational and managerial response to these challenges was the formation of centers of excellence. These structures are created under leading scientific organisations and universities. China is actively using this method. In OECD countries, the number of such centers has already exceeded 320. Centers of excellence are a special form of financing allowing reducing the time of the scientific and innovation cycle. For Russia, it is important in terms of eliminating the critical dependence on a number of import items. Centers of excellence are seen as gravitational centers for scientific and technological consortia and even 
chains of value added. Nowadays, it is the most modern organisational device for integrating science, technology and the market.

It is important to note that today competition in global high-tech markets is no longer between countries, but between consortia and value chains. The ultimate goal of innovative growth and national competitiveness is the retention of highly skilled and, accordingly, highly paid jobs in the territory of the country. Without achieving this goal, living standards and quality of life cannot be improved.

\section{Conclusion}

On balance, the overall picture seems to be that in the long term the efficiency of international positioning will depend not only on "military muscles" (although the polycentric world order is more dangerous than bipolar and unipolar structures), but also on Russia's ability to promote innovative development, improve the quality of life and living standards, and build profitable relationships with other major players in the international arena.

\section{References}

1. Anchishkin A. I. Prognozirovanie tempov i faktorov ekonomicheskogo rosta [Forecasting rates and factors of economic growth]. Moscow: MAKS Press, 2003.

2. Bodrunov S. D. Novoe industrial'noe obshchestvo. Proizvodstvo. Ekonomika. Instituty [New industrial society. Manufacturing. Economy. Institutions]. Ekonomicheskoe vozrozhdenie Rossii - Economic Revival of Russia, 2016, no. 2 (48), pp. 5-14.

3. Kondratyev V. B. Otrasli i sektora global'noy ekonomiki: osobennosti i tendentsii razvitiya [Industries and sectors of global economy: specifics and tredns of development]. Moscow: Mezhdunarodnye otnosheniya Publ., 2015.

4. Lukas R. E. Lektsii po ekonomicheskomu rostu [Lectures on economic growth]. Moscow: Gaydar Institute, 2013.

5. Perez C. Tekhnologicheskie revolyutsii i finansovyy kapital. Dinamika puzyrey i periodov protsvetaniya [Technological revolutions and financial capital. Dynamics of bubbles and golden ages]. Moscow: Delo ANKh Publ., 2011.

6. Polterovich V.M., Popov V.V. Evolyutsionnaya teoriya ekonomicheskoy politiki [Evolutionary theory of economic policy]. Voprosy ekonomiki - The Issues of Economics, 2006, no. 7, pp. 4-23.

7. Schumpeter J. Teoriya ekonomicheskogo razvitiya [The theory of economic development]. Moscow: Progress Publ., 1982

8. Helpman E. Zagadka ekonomicheskogo rosta [The mystery of economic growth]. Moscow: Gaydar Institute, 2011.

9. Berry B. Long-Wave Rhythms in Economic Development and Political Behavior. Baltimore, MD: Johns Hopkins University Press, 1991.

10. Gunningham N., Grabosky P. Smart Regulation: Designing Environmental Policy. Oxford University Press, 2004.

11. Krugman P. Geography and Trade. Cambridge: MIT Press, 1991.

12. Meadows D. H., Meadows D. L., Randers J., Behrens W. W. The Limits to Growth. $5^{\text {th }}$ ed. London: Pan Books Ltd, 1979.

13. North D. C. Institutions and Economic Growth: An Historical Introduction. World Development, 1989, no. 17 (9), pp. 1319-1332.

14. Palley T. I. Growth Theory in a Keynesian Mode: Some Keynesian Foundations for New Endogenous Growth Theory. Journal of Post-Keynesian Economics, 1996, no. 19 (1), pp. 113-135.

15. Perrow C. A Framework for the Comparative Analysis of Organisations. American Sociological Review, 1967, no. 32, pp. 194-208. 
16. Rostow W. W. The Stages of Economic Growth: A Non-Communist Manifesto. Cambridge University Press, 1960.

17. Harrod R. F. Towards a Dynamic Economics: Some Recent Developments of Economic Theory and Their Application to Policy. London: Macmillan, 1948.

18. Solow R. M. A Contribution to the Theory of Economic Growth. The Quarterly Journal of Economics, 1956, no. 70 (1), pp. 65-94.

19. Woodward J. Industrial Organisation: Theory and Practice. L.: Oxford University Press, 1965.

\title{
Экономика России: отечественные дискуссии и международное позиционирование
}

\author{
А.А. Дьнкин
}

Статья посвящена исследованию приоритетов и векторов развития отечественной экономики в контексте международного позиционирования России в мировом пространстве. Определены экономические циклы в новейшей экономической истории России, выявлена специфика кризиса 2014 г. и особенности посткризисного восстановления экономики. Установлено, что внутри страны имеются «зоны роста», которые могут быть источниками устойчивого развития экономики. В то же время автор выделяет три ключевых фактора, которые могут препятствовать России в достижении экономических целей: замедление темпов экономического роста в Китае; потенциально возможное увеличение объемов добычи нефти; ухудшение делового климата и негативные ожидания экономических акторов в ведущих странах Евросоюза. Эти и другие факторы, наряду с нерешенными проблемами инновационной активности и конкуренции технологий в России, могут существенно ухудшить ожидаемый рост отечественной экономики в $1,5-2,0 \%$ ВВП.

Ключевые слова: устойчивый рост; промышленная политика; инновации; технологическая конкуренция; структурные реформы; институциональная модернизация.

Источники

1. Анчишкин А.И. Прогнозирование темпов и факторов экономического роста. М.: МАКС Пресс, 2003.

2. Бодрунов С. Д. Новое индустриальное общество. Производство. Экономика. Институты // Экономическое возрождение России. 2016. №2 (48). С. 5-14.

3. Кондратьев В.Б. Отрасли и секторы глобальной экономики: особенности и тенденции развития. М.: Международные отношения, 2015.

4. Лукас Р. Э. Лекции по экономическому росту: пер. с англ. М.: Изд-во Института Гайдара, 2013.

5. Перес К. Технологические революции и финансовый капитал. Динамика пузырей и периодов процветания / пер. с англ. Ф. В. Маевского. М.: Дело АНХ, 2011.

6. Полтерович В. М., Попов В. В. Эволюционная теория экономической политики // Вопросы экономики. 2006. №7. С. 4-23.

7. Шумпетер Й. Теория экономического развития. М.: Прогресс, 1982.

8. Хелпман Э. Загадка экономического роста: пер. с англ. М.: Изд-во Института Гайдара, 2011.

9. Berry B. Long-Wave Rhythms in Economic Development and Political Behavior. Baltimore, MD: Johns Hopkins University Press, 1991.

10. Gunningham N., Grabosky P. Smart Regulation: Designing Environmental Policy. Oxford University Press, 2004.

11. Krugman P. Geography and Trade. Cambridge: MIT Press, 1991.

12. Meadows D. H., Meadows D. L., Randers J., Behrens W. W. The Limits to Growth. $5^{\text {th }}$ ed. L.: Pan Books Ltd, 1979. 
13. North D. C. Institutions and Economic Growth: An Historical Introduction // World Development. 1989. No. 17 (9). P. 1319-1332.

14. Palley T. I. Growth Theory in a Keynesian Mode: Some Keynesian Foundations for New Endogenous Growth Theory // Journal of Post-Keynesian Economics. 1996. No. 19 (1). P. 113-135.

15. Perrow C. A Framework for the Comparative Analysis of Organisations // American Sociological Review. 1967. No. 32. P. 194-208.

16. Rostow W. W. The Stages of Economic Growth: A Non-Communist Manifesto. Cambridge University Press, 1960.

17. Harrod R. F. Towards a Dynamic Economics: Some Recent Developments of Economic Theory and Their Application to Policy. L.: Macmillan, 1948.

18. Solow R. M. A Contribution to the Theory of Economic Growth // The Quarterly Journal of Economics. 1956. No. 70 (1). P. 65-94.

19. Woodward J. Industrial Organisation: Theory and Practice. L.: Oxford University Press, 1965.

Сведения об авторе:

А. А. Дынкин, академик РАН, д-р экон.

наук, проф., президент

Контактный телефон: (499) 128-05-14

Национальный исследовательский институт мировой экономики и международных

e-mail: dynkin@imemo.ru отношений им. Е.М. Примакова РАН 117997, РФ, г. Москва, ул. Профсоюзная, 23

Ссылка для изитирования:

Dynkin A.A. Russia’s Economy: Domestic Discussions and International Positioning // Известия Уральского государственного экономического университета. 2017. № 5 (73). С. 34-43.

For citation:

Dynkin A. A. Russia's Economy: Domestic Discussions and International Positioning. Izvestiya Uralskogo gosudarstvennogo ekonomicheskogo universiteta - Journal of the Ural State University of Economics, 2017, no. 5(73), pp. 34-43. 